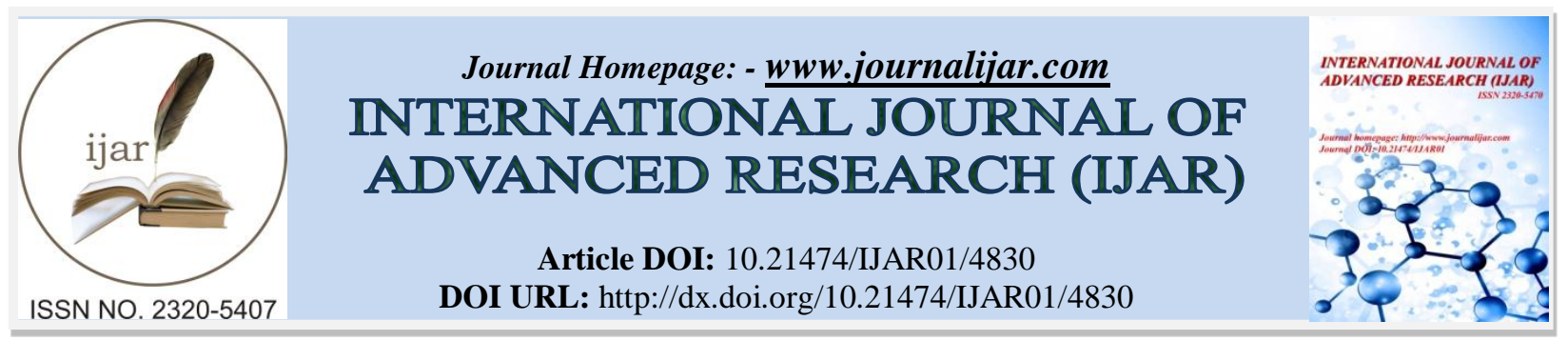

RESEARCH ARTICLE

\title{
AMELIORATING EFFECT OF VITAMIN-E AGAINST CADMIUM (CD) INDUCED BRAIN OXIDATIVE DAMAGE IN ALBINO RATS.
}

Bhuvaneswari Devi $\mathbf{C}^{1}$ and Kiran Kumari, $\mathrm{K}^{2}$.

1. Department of Cell Biology and Neuroscience, University of California Riverside, CA, USA.

2. Department of Zoology, S.P.W. Degree and PG College, Affiliated to Sri Venkateswara University, Tirupati517502, India.

\section{Manuscript Info}

Manuscript History

Received: 12 May 2017

Final Accepted: 14 June 2017

Published: July 2017

Key words:-

Oxidative stress, Cadmium, Vitamin-E,

GPX, GST, GR, XO, LP

\section{Abstract}

Acute exposure to moderately high concentrations of freshly generated cadmium oxide fumes $\left(200-500 \mu \mathrm{g}\right.$ cadmium $\left./ \mathrm{m}^{3}\right)$ may cause symptoms like the metal fume fever. The present study addressed the effect of Cadmium (Cd) on Oxidative Stress in rat brain. The three months rats were exposed to $\mathrm{Cd}$ intraperitonially at concentrations of low dose $(1.5 \mathrm{mg} / \mathrm{kg}$ bw) and high dose $(3 \mathrm{mg} / \mathrm{kg}$ bw) for a period of three weeks. A separate batch of low dose and high dose of $\mathrm{Cd}$ exposed rats received Vitamin-E intraperitonially for a week. In this study, we have examined the Glutathione peroxidase (GPX) activity, Glutathione reductase (GR) activity, Glutathione-stransferase (GST) activity, Xanthine oxidase (XO) activity levels and Lipid peroxidation (LP) in three brain regions, Cerebral Cortex, Cerebellum, and Hippocampus. We assessed the biochemical end points indicative of oxidative Stress in these three brain regions. The GPX, GR, and XO activity levels showed significant decrease and the GST activity, LP levels showed significant increase over control rats in dose dependent manner. The exposure to Vitamin-E however to low and high dose of Cd showed recovery, the GPX, GR, and XO activity levels were increased and decreased GST activity, Lipid Peroxidation were observed. The results may be attributed to the reason that the $\mathrm{Cd}$ exposure disrupts the functioning of brain which resulted in oxidative deficits. The Vitamin-E lessened the $\mathrm{Cd}$ burden in the brain as effective chelating agent decreasing the oxidative stress.

Copy Right, IJAR, 2017,. All rights reserved.

\section{Introduction:-}

Cadmium (Cd) is a highly toxic element that is naturally present in all parts of the environment, including food, water, and soil (Sherlock, 1984). It is also present in cigarette smoke, representing a significant source of exposure (Stohs, 1997). Cadmium accumulates and proves to cause severe damage to a variety of organs such as lung, brain, testis, kidney, liver, blood system and bone (Manca, 1991). Pneumonitis, pulmonary emphysema, interstitial fibrosis together with cancer is a frequent response to cadmium exposure (Brandao et al., 2007). Because of its characteristics as a lung carcinogen, cadmium has been classified as a category carcinogen (human carcinogen) by the International Agency for Research on Cancer and the National Toxicology Program of the USA (Waisberg et al.,

Corresponding Author:- Bhuvaneswari Devi C.

Address:- Department of Cell Biology and Neuroscience, University of California Riverside, CA, 
2003). Acute inhalation of sufficient exposure of cadmium can cause both a chemical pneumonitis and pulmonary edema from the toxic effect to the alveolar epithelium and endothelium (Newman et al., 1996). Within 24h of exposure, workers develop shortness of breath, fever, and fatigue, which can progress to pulmonary edema and death (Fernandez, 1996). Chronic exposure to cadmium dusts and fumes has been suspected as a cause of emphysema, obstructive lung disease, pulmonary fibrosis, and lung cancer. Exposure of adult rats to low or moderate doses of Cd induced lipid peroxidation (LP) in all tissues, mainly lung and brain (Manca, 1991). Monroe and Halvorsen, 2006 provided evidence that $\mathrm{CdCl} 2$ increases oxidative stress in nervous cells. In experimental studies with animals, cadmium can induce neurotoxicity with a wide spectrum of clinical entities including neurological disturbance (Viaene et al., 2000). Changes in the normal neurochemistry of the brain (Gutierrez-Reyes et al., 1998), several authors have shown that antioxidants should be one of the important components of an effective treatment of cadmium poisoning (Valko et al., 2006). Accordingly, to prevent undesired oxidative damage induced by reactive species, organisms are equipped with several lines of antioxidant defence. Vitamin $\mathrm{C}$ is an aqueous phase antioxidant has been established for many decades and has several important roles. It modulates intracellular redox status through maintaining sulfhydryl compounds, including glutathione, in their reduced state. It has been suggested to repair protein hydroperoxides, through regeneration of parent amino acids by reduction. Also, it serves to maintain membrane alpha tocopherol and enzyme activities including hepatic mixed function oxidase activity (Suberlich et al., 1994). Gupta and Kar, (1998) reported that vitamin C can prevent increased lipid peroxidation levels resulting from cadmium toxicity. Vitamin $\mathrm{C}$ could serve as an effective antioxidant against restraint stress induced pro-oxidant status and increase the antioxidant enzyme activity in rat brain (Zaidi et al., 2004). In view of the above studies mentioned the present study has implicated the importance of antioxidants such as vitamin $\mathrm{E}$ in protecting living organism against the toxic effect of cadmium exposure in the brain regions of young Albino rats.

\section{Materials And Methods:-}

\section{Chemicals:-}

Cadmium (Cd) and Vitamin E were selected as test chemicals. The chemicals used in this study namely Thiobarbutric acid, Glutathione oxidized, NADPH, DTNB, Reduced glutathione, Epinephrine were obtained from Sigma, USA. The remaining chemicals obtained from Qualigens and Loba Chemie, India.

\section{Procurement and maintenance of experimental animals:-}

The young and adult albino rats (1 month and 3 months old) (Wistar) were purchased from Sri Venkateswara traders, Bangalore and maintained in the animal house of Watson Life Sciences, Tirupati. The animals were housed in transparent plastic cages with hardwood bedding in a room maintained at $28^{\circ} \pm 2^{\circ} \mathrm{C}$ and relative humidity $60 \pm 10 \%$ with a 12 hour light/day cycle. The animals were fed in the laboratory with standard pellet diet supplied by Sri Venkateswara traders, Bangalore and water ad libitum. The protocol and animal use were approved by Y.V. University, India.

\section{Animal exposure to Cd and Vitamin E:-}

The young albino rats (3 months) were exposed to Cd (Low dose: $1.5 \mathrm{mg} / \mathrm{kg} / \mathrm{body}$ weight and High dose: $3 \mathrm{mg} / \mathrm{kg} /$ body weight). A separate batch of low dose and high dose of $\mathrm{Cd}$ exposed rats received vitamin-E $(5 \mathrm{mg} / \mathrm{kg} /$ body weight) intraperitoneally for a week. The control animals received only deionized water without Cd. After the period of dosage, the animals were sacrificed through cervical dislocation and the tissues were stored at $80^{\circ} \mathrm{C}$ for the further biochemical analysis.

\section{Biochemical Studies:-}

\section{Preparation of Brain Mitochondrial Fraction:-}

Brain mitochondrial fractions were prepared following Lai and Clark, 1979. Briefly, the tissue was homogenized in 5 volumes (w/v) of SET buffer ( $0.25 \mathrm{M}$ sucrose, $10 \mathrm{mM}$ Tris-HCl, and $1 \mathrm{mM}$ EDTA, $\mathrm{pH}$ 7.4). The homogenate was first centrifuge at $800 \mathrm{~g}$ for $10 \mathrm{~min}$ at $4^{\circ} \mathrm{C}$, and then the supernatant was centrifuged at 10,000 $\mathrm{g}$ for $20 \mathrm{~min}$ at $4^{\circ} \mathrm{C}$. Then the pellet of mitochondrial fraction was suspended in SET buffer.

Glutathione peroxidase (GPx) activity:-

GPx activity in the mitochondrial fraction of rat kidney was assayed as described by Rotruck et al., (1973). The reaction mixture contained $0.2 \mathrm{ml}$ of EDTA, $0.2 \mathrm{ml}$ of $4 \mathrm{mM}$ sodium azide, $0.2 \mathrm{ml}$ of glutathione reduced, $0.2 \mathrm{ml}$ of $\mathrm{H}_{2} \mathrm{O}_{2}, 0.4 \mathrm{ml}$ of $0.32 \mathrm{M}$ Sodium pyrophosphate buffer ( $\mathrm{pH}-7.0$ ), $0.1 \mathrm{ml}$ of enzyme source. Then the reaction mixture 
was incubated at $37^{\circ} \mathrm{C}$ for $10 \mathrm{~min}$. Then the reaction was arrested by adding of $0.5 \mathrm{ml} 10 \%$ TCA. Then centrifuged at $2000 \mathrm{rpm}$ for $10 \mathrm{~min}$. To $0.5 \mathrm{ml}$ of supernatant, $3.0 \mathrm{ml}$ of $0.3 \mathrm{M}$ disodium hydrogen phosphate and $1.0 \mathrm{ml}$ of DTNB were added and the reaction was read at $412 \mathrm{~nm}$ in spectrophotometer. The enzyme activity was expressed as $\mu \mathrm{mole} / \mathrm{min} / \mathrm{mg}$ protein.

\section{Glutathione reductase (GR):}

GR activity in the mitochondrial fraction of rat brain was assayed as described by Staal et al., (1969). The reaction mixture in a final volume of $3.0 \mathrm{ml}$ contained, $1.0 \mathrm{ml}$ of $0.3 \mathrm{M}$ Sodium phosphate buffer $(\mathrm{pH}-6.8), 0.5 \mathrm{ml}$ of $250 \mathrm{mM}$ EDTA, $0.5 \mathrm{ml}$ of $12.5 \mathrm{mM}$ GSSG, $0.7 \mathrm{ml}$ of distilled water, $0.2 \mathrm{ml}$ of $30 \mathrm{mM}$ NADPH and $0.1 \mathrm{ml}$ of enzyme extract. Changes in absorbance were recorded at $340 \mathrm{~nm}$ in a spectrofluorometer. The enzyme activity was expressed as $\mu$ moles of NADPH oxidised/mg protein/min.

\section{Xanthine oxidase (XO) activity:-}

Xanthine oxidase activity was estimated by the method given in Worthington Manual (2004). The assay mixture contained $1.9 \mathrm{ml}$ of phosphate buffer $(\mathrm{pH} 7.5), 1.0 \mathrm{ml}$ of hypoxanthine and $0.1 \mathrm{ml}$ of enzyme source. Increase in absorbance was recorded and absorbance was recorded at $290 \mathrm{~nm}$ from the linear curve. The rate is proportional to enzyme concentration within limits of 0.01-0.02 units per test. The activity was expressed as moles of $\mu$ urate formed $/ \mathrm{mg}$ protein/min.

\section{Glutathione-S-transferase (GST) activity:-}

GST activity in the mitochondrial fraction of rat brain was assayed by using 1-chloro-2, 4-dinitro benzene (CDNB) (at $340 \mathrm{~nm}$ ) substrate as described by Habig et al., (1974).

The reaction mixture in a final volume of $3.0 \mathrm{ml}$ contained: $150 \mathrm{mM}$ phosphate buffer (pH 7.5), $1 \mathrm{mM} \mathrm{CDNB}, 5$ $\mathrm{mM}$ glutathione (GSH) and an appropriate amount of enzyme protein. The reaction was initiated by the addition of $\mathrm{GSH}$ and incubated at $37^{\circ} \mathrm{C}$. The formation of a thioether by the conjugation of CDNB to GSH was monitored at $340 \mathrm{~nm}$ in a spectrofluorometer. Thioether concentration was determined from the slopes of initial reaction rates. The activity was expressed as $\mu$ moles of thioether formed/mg protein/min, where one unit of enzyme activity is defined as one $\mu$ moles of thioether formed $/ \mathrm{mg}$ protein $/ \mathrm{min}$.

\section{Lipid peroxidation;-}

The level of lipid peroxidation in the tissues was measured in terms of malondialdehyde (MDA; a product of lipid peroxidation) content and determined by using the thiobarbituric acid (TBA) reagent. The reactivity of TBA is determined with minor modifications of the method adopted by Hiroshi et al., (1979).

To $2.5 \mathrm{ml}$ of homogenate, $0.5 \mathrm{ml}$ of saline ( $0.9 \%$ sodium chloride), $1.0 \mathrm{ml}$ of $(20 \% \mathrm{w} / \mathrm{v})$ trichloroacetic acid (TCA) were added. The contents were centrifuged for 20 minutes on a refrigerated centrifuge at $4000 \mathrm{x} \mathrm{g}$. To $1.0 \mathrm{ml}$ of supernatant, $0.25 \mathrm{ml}$ of TBA reagent was added and the contents were incubated at $95^{\circ} \mathrm{C}$ for $1 \mathrm{hr}$. $1 \mathrm{ml}$ of $\mathrm{n}$-butanol was added to it. After thorough mixing, the contents were centrifuged for 15 minutes at $4000 \mathrm{~g}$ in a refrigerated centrifuge. The organic layer was transferred into a clear tube and its absorbance was measured at $532 \mathrm{~nm}$. The rate of lipid peroxidation was expressed as $\mu$ moles of malondialdehyde formed/g wet wt. of tissue.

\section{Estimation of protein content:-}

Protein content of the kidney was estimated by the method of Lowry et al., (1951). 1\% (W/V) homogenate was prepared in $0.25 \mathrm{M}$ ice cold sucrose solution. To $0.5 \mathrm{ml}$ of crude homogenate, $1 \mathrm{ml}$ of $10 \%$ TCA was added and the samples were centrifuged at $1000 \mathrm{~g}$ for $15 \mathrm{~min}$. The residue was resuspended in $0.5 \mathrm{ml}$ of $1 \mathrm{~N} \mathrm{NaOH}$. And $4 \mathrm{ml} \mathrm{of}$ alkaline copper reagent was added followed by $0.4 \mathrm{ml}$ of folin-phenol reagent $\left(1: 1\right.$ folin: $\left.\mathrm{H}_{2} \mathrm{O}\right)$. The color was measured at $600 \mathrm{~nm}$ in a UV- Vis spectrophotometer (Hitachi model U-2000) against blank. The protein standard graph was prepared using Bovine serum albumin. The protein content of the tissues was calculated using the standard graph.

\section{Statistical treatment of the data:-}

The mean and standard deviation (SD), analysis of variance (ANOVA) was calculated using standard statistical software package. 


\section{Results:- \\ Glutathione peroxidase activity:-}

From Fig.1, it was observed that the increased mitochondrial GPx activity observed in Cerebral Cortex (CC), Cerebellum (CB) and Hippocampus (HP). The GPx activity in Cd-exposed (both low and high dose) rats was decreased when compared to control. However, the effect was highly pronounced in high dose exposed animals compared to the low dose exposed animals. GPx activity was found to be increased in the animals supplemented with Vitamin E along with low and high dose of Cd-exposed animals. Among the brain regions, $\mathrm{CC}$ was found to be more susceptible compared to the other brain regions.

\section{Glutathione Reductase activity:-}

From Fig.2, it was observed that the mitochondrial GR activity was found high in CC followed by CB, and HP. The GR activity in mitochondrial fraction of Cd-exposed (both low and high dose) rats was decreased when compared to control. However, the effect was highly pronounced in high dose exposed animals compared to the low dose exposed animals. The GR activity increased with vitamin E supplementation in low and high dose Cd-exposed animals in all three regions of brain $\mathrm{CC}, \mathrm{CB}$ and $\mathrm{HP}$.

\section{Xanthine oxidase activity:-}

From Fig.3, it was observed that the XO mitochondrial fraction of Cd-exposed (both low and high dose) rats was decreased when compared to control. However, the effect was highly pronounced in high dose exposed animals compared to the low dose exposed animals. XO was found to be increased in the animals supplemented with Vit-E along with low and high dose Cd-exposed animals. Among the brain regions, $\mathrm{CC}$ was found to be more susceptible compared to the other brain regions.

\section{Glutathione-S-transferase activity:-}

From Fig.4, it was observed that the activity of GST was found highest in CC followed by CB and HP. The GST activity in Cd-exposed (both low and high dose) rats was decreased when compared to control. However, the supplementation with vitamin E decreased the GST activity in low and high dose Cd-exposed animals. The low dosed animals showed more recovery.

\section{Lipid peroxidation:-}

The mitochondrial lipid peroxidation was calculated in terms of MDA levels. From Fig.5, it was observed that the MDA levels in mitochondrial fraction of Cd-exposed (both low and high dose) rats were recorded high when compared to controls. The effect was highly pronounced in high dose exposed animals compared to the low dose exposed animals. However, the vitamin E reversed the Cd effect and MDA levels were found decreased in low and high dose $(1.5 \mathrm{mg} / \mathrm{kg}$ body weight and $3 \mathrm{mg} / \mathrm{kg}$ body weight) Cd-exposed animals in all the three brain regions.

\section{Protein content:-}

From Fig.6, it was observed that the protein content in mitochondrial fraction of Cd-exposed (both low and high dose) rats was decreased when compared to control. However, the effect was highly pronounced in high dose exposed animals compared to the low dose exposed animals. Protein content was found increased in the animals supplemented with Vitamin E along with low and high dose Cd-exposed animals. 


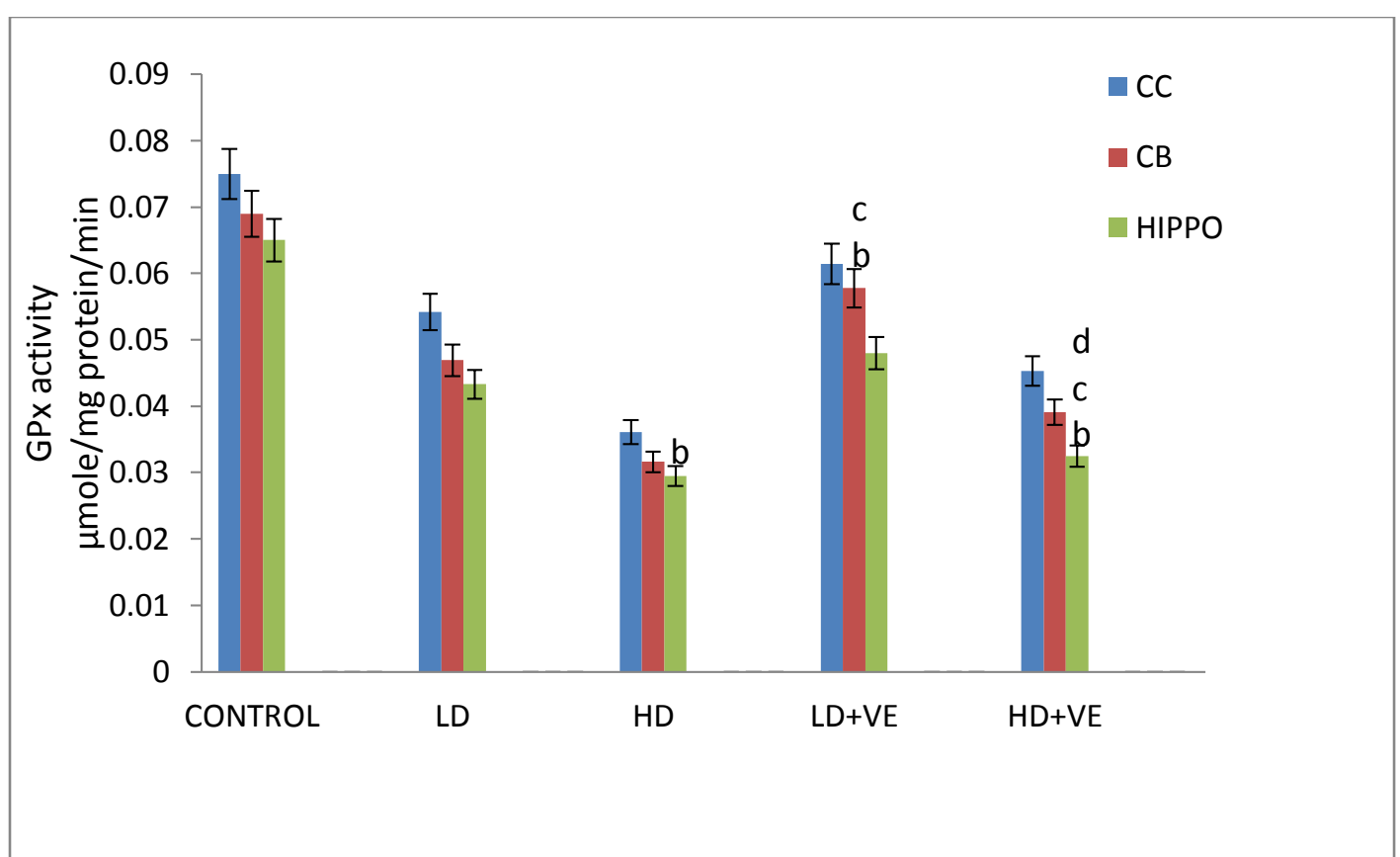

Fig. 1:- Protective effect of Vitamin E against low dose(LD) (1.5mg/kg bw) and high dose (HD) (3mg/kg body weight) of Cd induced alteration in GPx levels in brain specific regions i.e. CC (Cerebral Cortex), CBM (Cerebellum) and HIPPO (Hippocampus). The rats treated with Cd through intraperitonially daily for a period of three weeks and with Vitamin $E$ for a week. Each bar represents mean $\pm S D(n=6)$. All values are extremely significant at $\mathrm{p}<0.0001$, except the values (bars) marked with a; compared with control, b; compared with LD, c; compared with HD, d; compared with LDV.

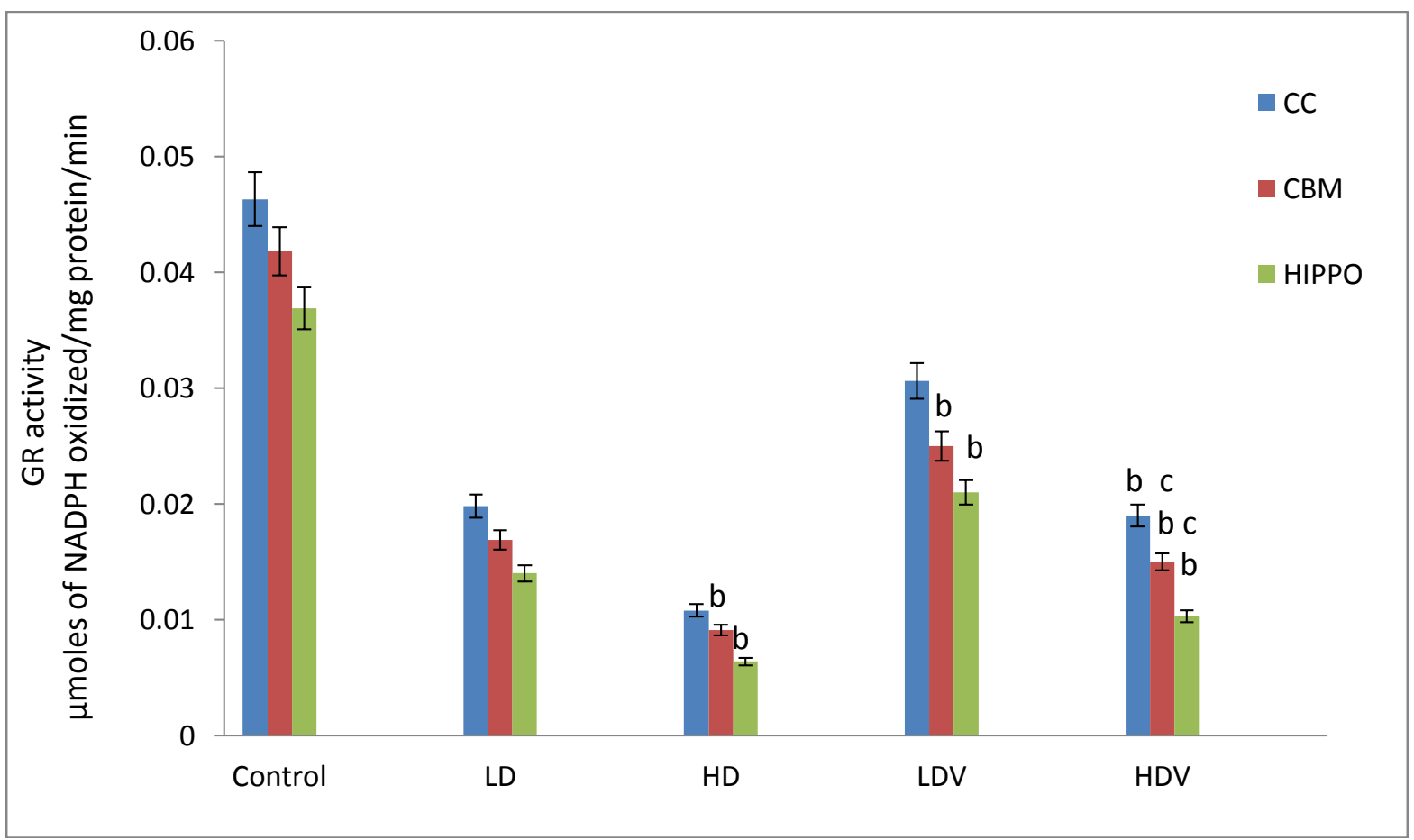

Fig. 2:- Protective effect of Vitamin E against low dose(LD) (1.5mg/kg bw) and high dose (HD) (3mg/kg body weight) of Cd induced alteration in GR levels in brain specific regions i.e. CC (Cerebral Cortex), CBM

(Cerebellum) and HIPPO (Hippocampus). The rats treated with Cd through intraperitonially daily for a period of three weeks and with Vitamin $\mathrm{E}$ for a week. Each bar represents mean $\pm \mathrm{SD}(\mathrm{n}=6)$. All values are extremely 
significant at $\mathrm{p}<0.0001$, except the values (bars) marked with a; compared with control, b; compared with LD, c; compared with HD, d; compared with LDV.

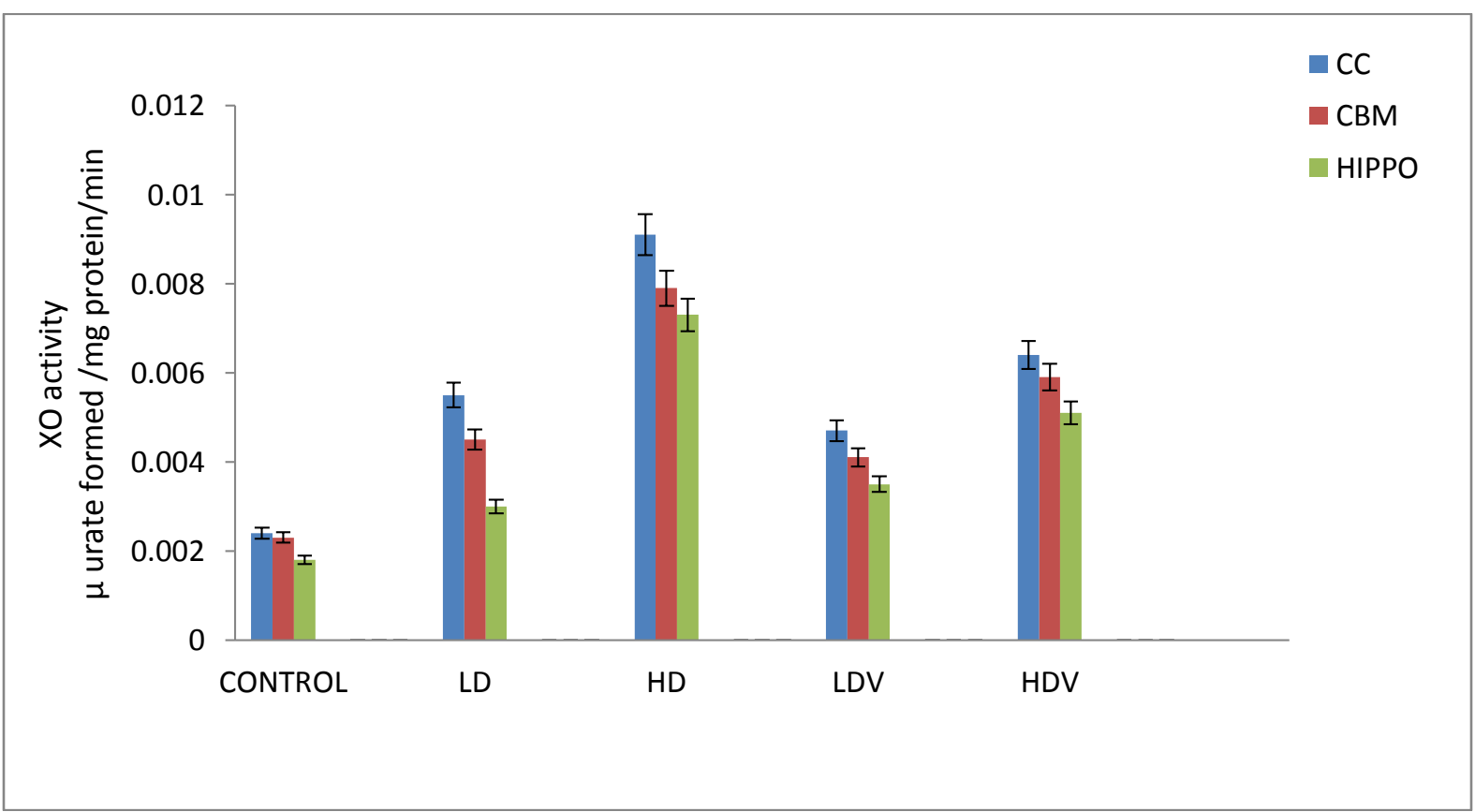

Fig. 3:- Protective effect of Vitamin $\mathrm{E}$ against low dose(LD) (1.5mg/kg bw) and high dose (HD) (3mg/kg body weight) of Cd induced alteration in XO levels in brain specific regions i.e. CC (Cerebral Cortex), CBM

(Cerebellum) and HIPPO (Hippocampus). The rats treated with Cd through intraperitonially daily for a period of three weeks and with Vitamin E for a week. Each bar represents mean $\pm S D(n=6)$. All values are extremely significant at $\mathrm{p}<0.0001$,

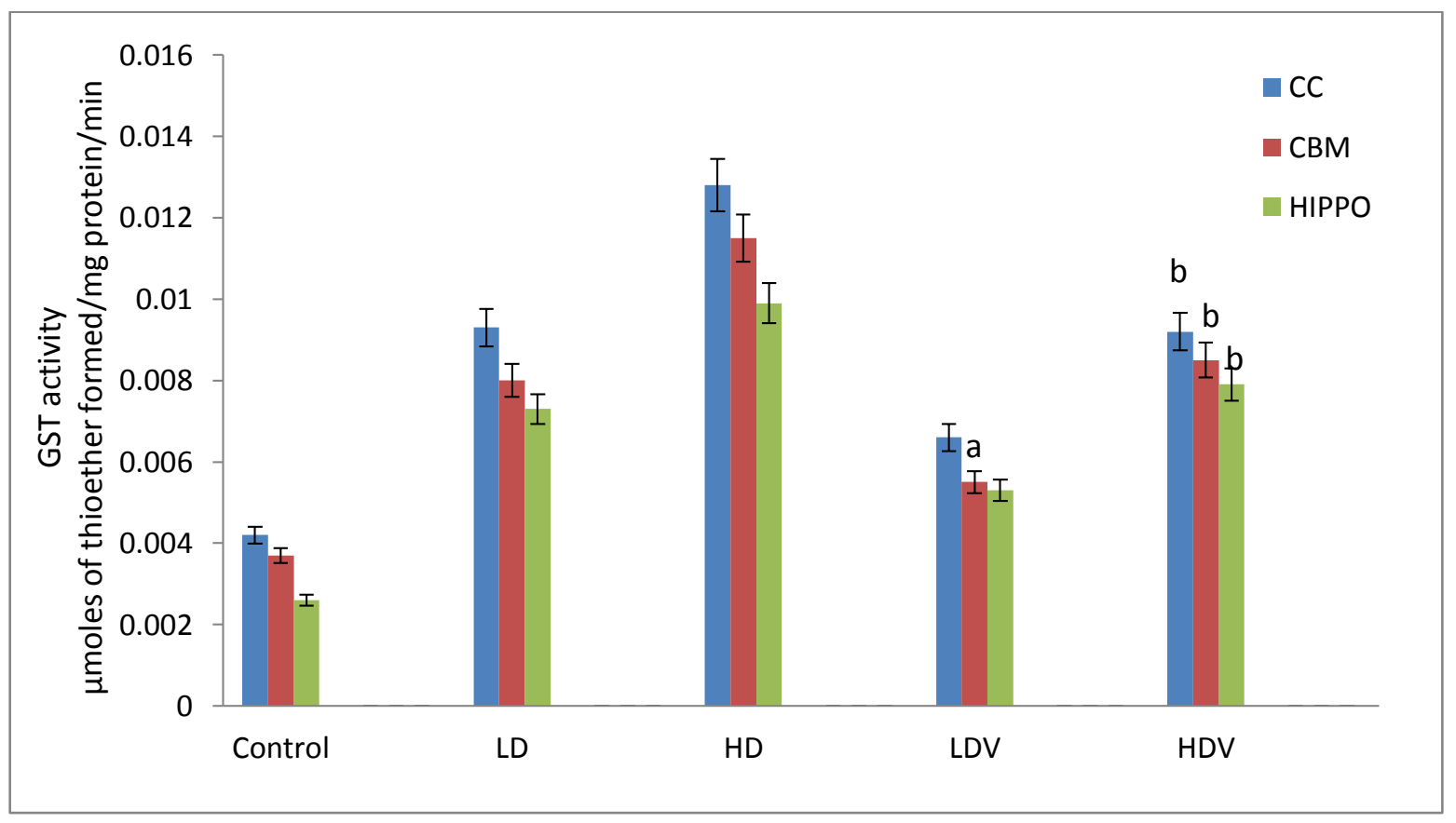

Fig.4:- Protective effect of Vitamin E against low dose(LD) $(1.5 \mathrm{mg} / \mathrm{kg}$ bw) and high dose (HD) (3mg/kg body weight) of Cd induced alteration in GST levels in brain specific regions i.e. CC (Cerebral Cortex), CBM

(Cerebellum) and HIPPO (Hippocampus). The rats treated with Cd through intraperitonially daily for a period of three weeks and with Vitamin E for a week. Each bar represents mean $\pm S D(n=6)$. All values are extremely 
significant at $\mathrm{p}<0.0001$, except the values (bars) marked with a; compared with control, b; compared with LD, c; compared with HD, d; compared with LDV.

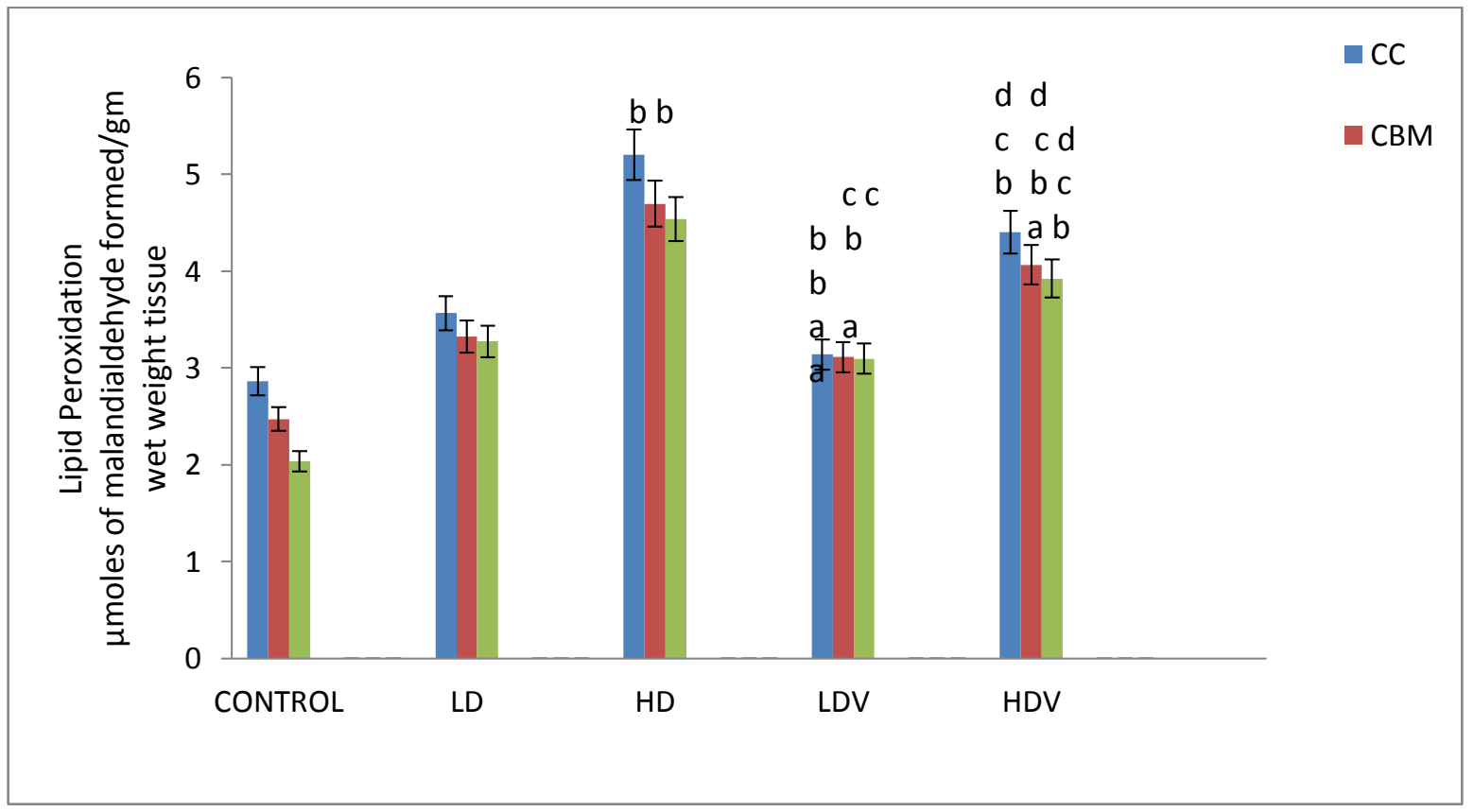

Fig. 5:- Protective effect of Vitamin E against low dose(LD) (1.5mg/kg bw) and high dose (HD) (3mg/kg body weight) of Cd induced alteration in LP levels in brain specific regions i.e. CC (Cerebral Cortex), CBM (Cerebellum) and HIPPO (Hippocampus). The rats treated with $\mathrm{Cd}$ through intraperitonially daily for a period of three weeks and with Vitamin $E$ for a week. Each bar represents mean $\pm S D(n=6)$. All values are extremely significant at $p<0.0001$, except the values (bars) marked with a; compared with control, b; compared with LD, c; compared with HD, d; compared with LDV.

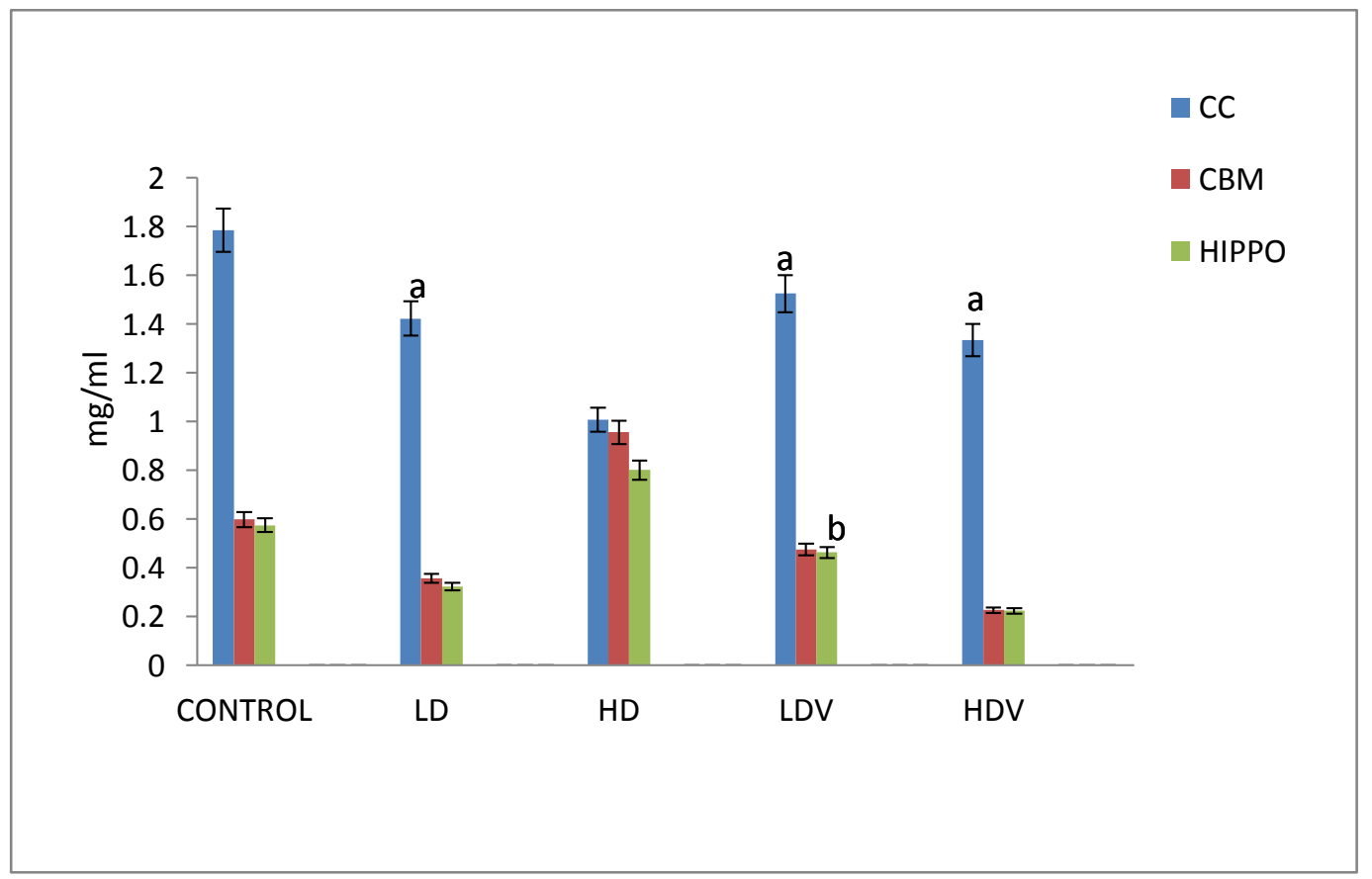

Fig. 6:- Protective effect of Vitamin E against low dose(LD) (1.5mg/kg bw) and high dose (HD) (3mg/kg body weight) of Cd induced alteration in Protein levels in brain specific regions i.e. CC (Cerebral Cortex), CBM (Cerebellum) and HIPPO (Hippocampus). The rats treated with Cd through intraperitonially daily for a period of 
three weeks and with Vitamin E for a week. Each bar represents mean \pm SD $(n=6)$. All values are extremely significant at $\mathrm{p}<0.0001$, except the values (bars) marked with a; compared with control, b; compared with LD, c; compared with HD, d; compared with LD+V.

\section{Discussion:-}

Cadmium has been recognized as one of the most toxic environmental and industrial pollutant. Cadmium is ubiquitous toxic metal that may induce oxidative damage by disturbing the prooxidant-antioxidant balance in tissues was observed in rats treated with cadmium (Kostic et al., 1993; Zikic et al., 1998; Pavlovic et al., 2001). The severity of intoxication depends upon the route, dose, and duration of exposure to the metal (Ognjanovic et al., 1995).

Our data showed that significant decrease in the activities of GPX, GR, XO and increased GST activity in both doses of $\mathrm{Cd}$ exposure. However, the effect was more in high dose exposed animals compared to the low dose exposed animals. And moreover, among the brain regions studied, cerebral cortex was found to be more vulnerable to the $\mathrm{Cd}$ induced neurotoxicity compared to the other brain regions. And we also observed a significant increase in lipid peroxidation (i.e., increased MDA level) in all the three brain regions of cd-exposed rats. Further, inhibition of antioxidant enzymes, viz., glutathione peroxidase, glutathione reductase in cadmium-exposed animals suggests disturbed antioxidant/pro-oxidant ratio, resulting in oxidative stress. A number of antioxidant defense systems, both enzymatic and nonenzymatic, operate to control excessive levels of ROS.

The brain is particularly sensitive to oxidative damage because of its high rate of oxidative metabolism (Pajovic et al., 2003). Cd also enhances the production of free radicals in the brain of adult rats and interferes with the antioxidant defense system that in turn leads to a Cd-induced alteration of the structural integrity of lipids (Shukla et al., 1996). In adult rats exposed to Cd, there was an increase of LP in the corpus striatum and cerebral cortex (Pal et al., 1993). (Nishimura et al., 2006) reported that $\mathrm{Cd}$ can enter the brain parenchyma and neurons and causes neurological alterations in humans (Rose et al., 1992) and animal models (Lukawski et al., 2005), leading to lower attention, hyper nociception, and olfactory dysfunction and memory deficits.

The GPx activity with Vitamin-E co-administration along with cadmium, this could be due to the supplements enhanced the antioxidative defense system protected against cadmium toxicity (Shaikh et al., 1999).

Cadmium causes significant increases LP concentrations in kidney of rat, since it cause Lipid peroxidation in numerous tissues (Kostic et al., 1993; Ognjanovic et al., 2003; El-Demerdash et al., 2004), superoxide ions, nitric oxide and $\mathrm{H}_{2} \mathrm{O}_{2}$ (Waisberg et al., 2003). The activity of LP was significantly lowered in rats co-supplemented with Vit-E supplement. This is due to the antioxidant and antioxidant defense systems protects cells from Cd-induced toxicity (Shaikh et al.,1999). The LP activity was much more lowered in rats supplemented with Vitamin E. This could be due to the Vitamin E was liposoluble antioxidant, has key role in scavenging free radicals and stabilizing the cell membranes thus maintaining their permeability. Moreover, it is known that the antioxidant (Vitamin E) may act synergistically preventing lipid peroxidation and cell destruction (El Demerdash et al., 2004). Since Vitamin E ( $\alpha$-tocopherol) is primarily located in cell membranes, it is possible that $\alpha$-tocopherol modifies the kinetics of distribution of cadmium in cell membranes, such that its delivery to neuron or glia cells may be impeded. However, our observation that cadmium concentration in the nervous system was not reduced by $\alpha$-tocopherol supplementation suggests that the benefits of $\alpha$-tocopherol treatment were not a result of changes in cadmium distribution in the nervous system. Rather our findings are consistent with the view that protective effects of $\alpha$ tocopherol against sub chronic high dose cadmium exposure might be due to its antioxidant properties, and this may have a major impact on improving the quality of life of individuals suffering from neurotoxicity caused by cadmium exposure.

\section{Acknowledgements:-}

This work was supported by DST grant No. SR/FT/LS-103/2009 (G), Govt. of India. 


\section{References:-}

1. Brandao, C., de Oliveira, R., Nogueira, R., Santos, W.C. 2007. Efficacy of diphenyl diselenide against cerebral and pulmonary damage induced by cadmium in mice. Toxicol Lett. 22 (173):181- 90.

2. El-Demerdash, F.M., Yousef, M.I., Kedwany, F.S., Baghdadi, H.H. 2004. Cadmium-induced changes in lipid peroxidation, blood hematology, biochemical parameters and semen quality of male rats: protective role of vitamin E and B-carotene. Food ChemToxicol. 42:1563-71.

3. Fernandez, M.A., Sanz, P., Palomar, M., Serra, J., Gadea, E. 1996. Fatal chemical pneumonitis due to cadmium fumes. Occup Med. 46:372-74.

4. Gupta, P., Kar, A. 1998. Role of ascorbic acid in cadmium-induced thyroiddysfunction and lipid peroxidation. $J$ ApplToxicol. 18:317- 20.

5. Gutierrez-Reyes, E., Albores, A., Rios, C. 1998. Increase of striatal dopamine release by cadmium in nursing rats and its prevention by dexamethasone-induced metallothionein. Toxicology. 131:145-54.

6. Habig, W.H., Pabst, M.J., Jakoby, W.D. 1974. Glutathione transferase, the first enzymatic step in mecapturic acid formation. J. Biol. Chem. 249: 7130-7139.

7. Hiroshi, O., Ohishi, N., Yagi, K., 1979. Assay of lipid peroxides in animal tissues by thiobarbituric acid reaction. Anal Biochem. 95: 351-358.

8. Kostić, MM., Ognjanović, B., Dimitrijević, S., Zikić, R.V., Stajn, A., Rosić, G.L., Zivković, R.V., 1993. Cadmium-induced changes of antioxidant and metabolic status in red blood cells of rats: in vivo effects. Eur $J$ Haematol. 51(2):86-92.

9. Lai, J.C., Clark, J.B., 1979. Preparation of synaptic and nonsynaptic mitochondria from mammalian brain. Meth. Enzymol. 55:51-60.

10. Lowry, O.M., Rosebrough, N.J., Farr, A.L., Randall, R.J. 1951. Protein measurement with Folin phenol reagent. J. Biol. Chem. 193:265-275.

11. Lukawski, K., Nieradko, B., Sieklucka-Dziuba, M. 2005. Effects of cadmium on memory processes in mice exposed to transient cerebral oligemia. NeurotoxicolTeratol. 27:575-84.

12. Manca, D., Ricard, A.C., Trottier, B., Chevalier, G. 1991. Studies on lipid peroxidation in rat tissues following administration of low and moderate doses of cadmium chloride. Toxicology. 67:303- 23.

13. Monroe, K.R., Halvorsen, W.S. 2006. Cadmium blocks receptor-mediated Jak/STAT signaling in neurons by oxidative stress. Free Radic Biol Med. 41: 493-502.

14. Newman, L. 1996. Metals. Occupational and Environmental Respiratory Disease, 1st ed. In: Harber P, Schenker MB, Balmes J, Eds. MO: Mosby St", Louis, 469-513.

15. Nishimura, Y., Yamaguchi, J.Y., Kanada, A. 2006. Increase in intracellular Cd $\left(2^{+}\right)$concentration of rat cerebellar granule neurons incubated with cadmium chloride: cadmium cytotoxicity under external Ca $\left(2^{+}\right)$- free condition. Toxicol In vitro. 20: 211-16.

16. Ognjanović, B., Ikić, R.V., Tajn, A., Saičić, Z.S., Kostić, M.M. "Petrović V.M. 1995. The effects of selenium on the antioxidant defense system in the liver of rats exposed to cadmium. Physiol Res. 44:293-300.

17. Ognjanovic, B.I., Pavlovic, S.Z., Maletic, S.D., Zikic, R.V., Stajn, A.S., Radojicic, R.M. 2003. Protective influence of vitamin $\mathrm{E}$ on antioxidant defense system in the blood of rats treated with cadmium. Physiol Res. 52:563-70.

18. Pajovic, S.B., Saicic, Z.S., Sasic, M.B., Petrovic, M.B. 2003. The effect ofovarian hormones on antioxidant enzyme activities in the brain of male rats. Physiol Rev. 52: 189-94.

19. Pal, R., Nath, R., Gill, D.K. 1993. Influence of ethanol on cadmium accumulation and its impact on lipid peroxidation and membrane bound functional enzymes $\left(\mathrm{Na}^{+}, \mathrm{K}^{+}\right.$, ATPase and acetylcholinesterase) in various regions of adult rat brain. Neurochem Int. 23: 451-58.

20. Pavlovic, S.Z., Onjanvoic, B.I., Stajn, A.S., Zikic, R.V., Saicic, Z.S., Petrovic V.M. 2001. The effects of coenzyme Q10 onblood ascorbic acid, Vitamin E and lipid peroxide in chronic cadmium intoxication. J Environ Pathol Toxicol Oncol. 20:133-144.

21. Rose, C.S., Heywood, P.G., Costanzo, R.M. 1992. Olfactory impairment after chronic occupational cadmium exposure. J Occup Med. 34:600-5.

22. Rotruck, J.T., Pope, A.L., Ganther, H.E. 1973. Selenium: biochemical role as a component of glutathione peroxidise purification assay. Science. 179:588-590.

23. Shaikh, Z.A., Vu, T.T., Zaman, K. 1999. Oxidative stress as mechanism of chronic cadmium induced hepatotoxicity and renal toxicity and protection by antioxidants. Toxicol App Pharm. 154: 256-263.

24. Sherlock, J.C. 1984. Cadmium in foods and the diet. Experientia. 40:152-56.

25. Shukla, A., Shukla, S.G., Srimal, R.C. 1996. Cadmium induced alterations in blood-brain barrier permeability and its possible correlation with decreased microvessel antioxidant potential in rat. Hum ExpToxicol. 15: 400-5. 
26. Staal, G.E., Visser, J., Veeger, C. 1969. Purification and properties of glutathione reductase of human erythrocytes. Biochim Biophys Acta. 185: 39-48.

27. Stohs, S.J., Bagchi, D., Bagchi, M. 1997. Toxicity of trace element in tobacco smoke. Inhal Toxicol. 9: 867-90.

28. Suberlich, H.A. 1994. Pharmacolgy of vitamin C. Annu Rev Nutr. 14: 371-91.

29. Valko, M., Rhodes, C.J., Moncol, J., Izakovic, M., Mazur, M. 2006. Free radicals, metals and antioxidants in oxidative stress-induced cancer. ChemBiol Interact. 160: 1-40.

30. Viaene, M.K., Masschelein, R., Leenders, J., Groof, M., De Swerts, L.J.V., Rels, H.A. 2000. Neurobehavioural effects of occupational exposure to cadmium: a cross sectional epidemiological study. Occup Environ Med. 57: $19-27$.

31. Waisberg, M., Joseph, P., Hale, B., Beyersmann, D. 2003. Molecular and cellular mechanisms of cadmium carcinogenesis. Toxicology. 192: 95-117.

32. Worthington Manual, 2004. Xanthine Oxidase Assay. Worthington Biochemical Corporation, USA, pp. 399401.

33. Zaidi, S.M.K., Banu, N. 2004. Antioxidant potentials of vitamins A, E and C in modulating oxidative stress in rat brain. Clin Chem Acta. 340: 22-33.

34. Zikić, R.V., Tajn, A., Ognjanović, B., Saičić, Z.S., Kostić, M.M., Pavlović, S.Z., Petrović, V.M. 1998. The effect of cadmium and selenium on the antioxidant enzyme activities in rat heart. $J$ Environ PatholToxicolOncol. 17: 259-264. 